\title{
Development of Ethical and Operational Guidelines for the Delivery of Surgical Care in a COVID-19 Referral Hospital
}

\author{
Alvin B. Caballes, MD, ${ }^{1}$ Marie Carmela M. Lapitan, MD, ${ }^{1,2}$ Claudine B. Lukban, MD, ${ }^{1}$ \\ Samantha G. Siahetong, MD, ${ }^{1}$ Maureen P. Villanueva, $\mathrm{MD}^{1}$ and Brent G. Viray, MD ${ }^{1}$ \\ ${ }^{1}$ Department of Surgery, Philippine General Hospital, University of the Philippines Manila \\ ${ }^{2}$ Institute of Clinical Epidemiology, National Institutes of Health, University of the Philippines Manila
}

\begin{abstract}
Introduction. The COVID-19 pandemic has not only resulted in a public health crisis but has also strained hospital services. The provision of surgical care should therefore also be guided by ethical, and whenever applicable, also legal, principles.
\end{abstract}

Methods. An integrative approach that covers clinical and ethical dimensions, as well as spans the spectrum of surgical care, is therefore necessary. This action research involved three key steps: 1) identification of ethical dilemmas related to the provision of surgical care during the COVID-19 pandemic; 2) preparation of clinical scenarios that highlight these dilemmas; and 3) determination of the appropriate options for the said scenarios, based on the best available evidence as well as most applicable ethical principles.

Results. Ethical theories included utilitarianism, human rights, and communitarianism. Ethical principles included non-maleficence, justice, autonomy, and beneficence. Values considered were duty, reciprocity, human life, efficiency, fairness, fidelity, ownership, social value, and fair innings. Also incorporated were informed consent, allocation principles, resource allocation, and triage. In terms of operational issues and surgical technical concerns, the following were considered: phased standards of care, categorization of interventions, prioritization, surgical approaches, infection control, diagnostics, patient welfare, staff welfare, operations protocols, surgical training, and communication. Key points derived from the ethical and technical considerations of surgical care delivery during the COVID-19 pandemic are presented.

Conclusion. This action research involving a review of the literature and stakeholder engagement has provided a concise ethical and technical resource for surgical administrators, practitioners, and trainees.

Key Words: COVID-19, pandemic, surgical care, ethics, guidelines

\section{INTRODUCTION}

The COVID-19 pandemic has not only resulted in a public health crisis but has also strained hospital services. The impact on the latter has not only been due to the influx of COVID-19 cases requiring inpatient care and the

Corresponding author: Marie Carmela M. Lapitan, MD Department of Surgery Philippine General Hospital University of the Philippines Manila Taft Avenue, Ermita, Manila 1000, Philippines

Institute of Clinical Epidemiology

National Institutes of Health

University of the Philippines Manila

Email: mmlapitan@up.edu.ph consequent resource requirements (e.g., more ventilators), but also from the considerable risk of disease transmission and the resulting manpower strains.

With the Philippine General Hospital (PGH) having been designated as a COVID-referral hospital, its surgical departments have had to hastily reorganize its processes to be able to provide services while observing infection control measures meant to ensure the safety of health personnel. While operational and even technical concerns 
are important given the current exigencies, these should not be the sole basis for the provision of surgical services. There are other dimensions, possibly equally important, which should not be overlooked. It must not be forgotten that the SARS-CoV-2 virus is the adversary, and reactive policies and procedures should not unduly harm either patients or health care workers.

The provision of surgical care should therefore also be guided by ethical, and whenever applicable, also legal, principles. An integrative approach that covers clinical and ethical dimensions, as well as spans the spectrum of surgical care, is therefore necessary. This work aimed to develop ethical and basic operational guidelines for the delivery of hospital surgical services during the COVID-19 pandemic. The guidelines are expected to better inform the practice of surgery and the delivery of surgical care in PGH, as well as significantly influence the conduct of surgery in other institutions, in the time of a pandemic and other public health crises.

\section{METHODS}

This was an action research, involving three key steps: (1) identification of ethical dilemmas related to the provision of surgical care during the COVID-19 pandemic; (2) preparation of clinical scenarios that highlight these dilemmas; and (3) determination of the appropriate options for the said scenarios, based on the best available evidence as well as most applicable ethical principles.

A search of the published literature and the internet and online resources was performed to identify relevant documents and sites that provide resources and materials that deal with the ethics of surgical practice in general, as well as those tailored for COVID or other pandemics. Clinical scenarios that can be anticipated by the surgical services of PGH were conceptualized. Ethical questions and operational issues related to these scenarios were formulated. Recommendations addressing the questions and issues were drafted, based on the ethical recommendations and best practices gathered from existing protocols, the current standard of care, and ethical and resource allocation guidelines.

The first draft of the guidelines was sent to representatives of the different cutting departments of the Philippine General Hospital, particularly the members of the Operating Room Management Team and those involved in the case prioritization of the hospital during the pandemic, and a patient representative, including a guide questionnaire, for their comments and recommendations. Based on the responses received, additional case scenarios were conceptualized to cover additional aspects of surgical care. The revised guideline was then widely disseminated for further stakeholder review. Administrators of surgical services in different hospitals nationally, regional surgical practitioners, and local ethicists were targeted in this second review to ensure applicability and generalizability of the recommendations. A legal review by a medicolegal practitioner was also done.

The study protocol was granted an exemption from review by the UP Manila Research Ethics Board. This study was funded by a grant from the Philippine General Hospital Expanded Hospital Research Office.

\section{RESULTS}

The literature review identified several ethical and technical concepts, which could be used to guide surgical care during a pandemic. Ethical theories included utilitarianism, human rights, and communitarianism. Ethical principles included non-maleficence, justice, autonomy, and beneficence. Values considered were duty, reciprocity, human life, efficiency, fairness, fidelity, ownership, social value, and fair innings. Also incorporated were informed consent, allocation principles, resource allocation, and triage. In terms of operational issues and surgical technical concerns, the following were considered: phased standards of care, categorization of interventions, prioritization, surgical approaches, infection control, diagnostics, patient welfare, staff welfare, operations protocols, surgical training, and communication.

Initially, 5 case scenarios were conceptualized including staff allocation, trauma care, hospital admission, emergency surgeries, and cancer surgery. After the first round of stakeholder engagements, an expansion of the scope of the guidelines included obstetric and neonatal surgeries and perioperative contingencies. A second stakeholder examination and a legal review provided an emphasis on informed consent and a clearer framing of the guidelines.

Mapping of the different ethical and technical concepts across the different clinical scenarios and surgical aspects of care is shown in Tables 1 and 2.

A total of 17 individuals reviewed the guideline and provided their critical analysis, recommendations and suggestions. This included four senior and four junior surgeons, of which two were practicing outside Metro Manila, two non-surgeons, two administrators of surgical services of hospitals other than PGH, one dean of a medical school, two ethicists one of whom is a lawyer, one medicolegal practitioner, and one patient representative.

A final set of guidelines, incorporating all the inputs, was prepared in an electronic format. After formal submission of the guidelines to the PGH Hospital Administration, an electronic book was published. This is currently accessible from the electronic library maintained by the Nuffield Council on Bioethics. ${ }^{1}$

The following are the key points derived from the ethical and technical considerations of surgical care delivery during the COVID-19 pandemic.

1. During a health crisis, physicians, including surgeons, are duty-bound to render service, subject to the provision of measures that assure their safety and welfare. 
Table 1. Ethical concepts and topics discussed in the different clinical scenarios/surgical aspects of care in the guidelines

\begin{tabular}{|c|c|c|c|c|c|c|c|c|}
\hline \multicolumn{2}{|r|}{ Chapter } & \multirow{2}{*}{$\begin{array}{c}\text { I } \\
\text { Staff } \\
\text { Allocation }\end{array}$} & \multirow{2}{*}{\begin{tabular}{|c|} 
II \\
$\begin{array}{c}\text { Trauma } \\
\text { Care }\end{array}$ \\
\end{tabular}} & \multirow{2}{*}{\begin{tabular}{|c|} 
III \\
Hospital Admission
\end{tabular}} & \multirow{2}{*}{\begin{tabular}{|c|} 
IV \\
$\begin{array}{c}\text { Emergency } \\
\text { Surgeries }\end{array}$ \\
\end{tabular}} & \multirow{2}{*}{\begin{tabular}{|c|} 
V \\
Cancer and \\
Time-Sensitive \\
Surgeries \\
\end{tabular}} & \multirow{2}{*}{\begin{tabular}{|c|} 
VI \\
Obstetric \\
and Neonatal \\
Surgeries
\end{tabular}} & \multirow{2}{*}{$\begin{array}{c}\text { VII } \\
\text { Perioperative } \\
\text { Contingencies }\end{array}$} \\
\hline & Topic & & & & & & & \\
\hline \multirow[t]{3}{*}{ Theory } & Utilitarianism & & & & & & & \\
\hline & Rights & & & & & & & \\
\hline & Communitarian & & & & & & & \\
\hline \multirow[t]{4}{*}{ Principles } & Non-Maleficence & & & & & & & \\
\hline & Justice & & & & & & & \\
\hline & Autonomy & & & & & & & \\
\hline & Beneficence & & & & & & & \\
\hline \multirow[t]{9}{*}{ Values } & \begin{tabular}{|l|} 
Duty \\
\end{tabular} & & & & & & & \\
\hline & Reciprocity & & & & & & & \\
\hline & Human Life & & & & & & & \\
\hline & Efficiency & & & & & & & \\
\hline & Fairness & & & & & & & \\
\hline & Fidelity & & & & & & & \\
\hline & Ownership & & & & & & & \\
\hline & \begin{tabular}{|l|} 
Social Value \\
\end{tabular} & & & & & & & \\
\hline & Fair Innings & & & & & & & \\
\hline \multirow{2}{*}{$\begin{array}{l}\text { Informed } \\
\text { Consent }\end{array}$} & Staff Volunteers & & & & & & & \\
\hline & Patients & & & & & & $\begin{array}{l}\text { Medically } \\
\text { reasonable } \\
\text { alternatives; } \\
\text { recommendation; } \\
\text { documentation } \\
\end{array}$ & $\begin{array}{l}\text { Advance } \\
\text { directives }\end{array}$ \\
\hline \multicolumn{2}{|c|}{ Code of Ethics } & $\begin{array}{l}\text { Ghost } \\
\text { surgery, call } \\
\text { for help }\end{array}$ & & & & & & $\begin{array}{l}\text { Differences } \\
\text { in opinion }\end{array}$ \\
\hline \multicolumn{2}{|c|}{ Allocation Principles } & & & $\begin{array}{l}\text { Equal treatment, } \\
\text { favor worst-off, } \\
\text { total benefits; } \\
\text { compassionate care; } \\
\text { social emergencies }\end{array}$ & & $\begin{array}{l}\text { Rationing; } \\
\text { social } \\
\text { characteristics } \\
\text { secondary; } \\
\text { beware rule } \\
\text { of rescue } \\
\end{array}$ & & \\
\hline \multicolumn{2}{|c|}{ Resource Allocation } & $\begin{array}{l}\text { Staff } \\
\text { Allocation }\end{array}$ & $\begin{array}{l}\text { Allocation } \\
\text { criteria }\end{array}$ & $\begin{array}{l}\text { Finite and non- } \\
\text { finite resources; } \\
\text { Withdraw or } \\
\text { withheld; rule-based } \\
\text { admissions criteria } \\
\end{array}$ & & & & \\
\hline \multicolumn{2}{|l|}{ Triage } & & $\begin{array}{l}\text { Primary } \\
\text { Triage }\end{array}$ & Secondary Triage & $\begin{array}{l}\text { Tertiary } \\
\text { Triage: } \\
\text { Patient } \\
\text { categories } \\
\end{array}$ & & & \\
\hline
\end{tabular}

2. In extreme pandemic conditions, when hospital manpower is lacking, surgeons may need to perform tasks outside their expertise or even assume non-surgical roles. Staff should be given training and repeated guidance on, as well as made to abide by, the necessary precautions to minimize infection risks.

3. Should surgical procedures be needed, these should be done or supervised by the most qualified staff.
4. Staff who may already be infected may continue to provide non-frontline work, and only within welldefined boundaries.

5. The status of hospital resource requirements, as well as available surgical manpower, should be reviewed regularly, and the appropriate staff allocation to priority areas ensured. Retraining, as well as counseling, should be provided especially during operational transition periods. 
Table 2. Surgical operational topics discussed in the different clinical scenarios/surgical aspects of care in the guidelines

\begin{tabular}{|c|c|c|c|c|c|c|c|}
\hline Chapter & I & II & III & IV & V & VI & VII \\
\hline Topic & $\begin{array}{c}\text { Staff } \\
\text { Allocation }\end{array}$ & Trauma Care & $\begin{array}{l}\text { Hospital } \\
\text { Admission }\end{array}$ & $\begin{array}{l}\text { Emergency } \\
\text { Surgeries }\end{array}$ & $\begin{array}{c}\text { Cancer and } \\
\text { Time-Sensitive } \\
\text { Surgeries }\end{array}$ & $\begin{array}{c}\text { Obstetric } \\
\text { and Neonatal } \\
\text { Surgeries }\end{array}$ & $\begin{array}{l}\text { Perioperative } \\
\text { Contingencies }\end{array}$ \\
\hline $\begin{array}{l}\text { Phased Stan- } \\
\text { dards of Care }\end{array}$ & & Crisis, Contingency & $\begin{array}{l}\text { Crisis, } \\
\text { Contingency }\end{array}$ & $\begin{array}{l}\text { Crisis, } \\
\text { Contingency }\end{array}$ & Contingency & & \\
\hline $\begin{array}{l}\text { Intervention } \\
\text { Categories }\end{array}$ & & & & $\begin{array}{l}\text { Immediate, } \\
\text { urgent, expedited, } \\
\text { elective }\end{array}$ & $\begin{array}{l}\text { time-critical } \\
\text { (MeNTS) }\end{array}$ & & \\
\hline Area concerns & & $\begin{array}{l}\text { Point, Assessment } \\
\text { prioritization, } \\
\text { Contact tracing }\end{array}$ & & & $\begin{array}{l}\text { Blood products, } \\
\text { Clinical trials } \\
\\
\end{array}$ & $\begin{array}{l}\text { Immuno- } \\
\text { compromised } \\
\text { pregnant } \\
\text { patients; COVID } \\
\text { obstetric risks; } \\
\text { perinatal and } \\
\text { neonatal care } \\
\end{array}$ & \\
\hline Prioritization & & & & $\begin{array}{l}\text { ICU allocation } \\
\text { pattern; triage } \\
\text { committee, } \\
\text { triage officer }\end{array}$ & $\begin{array}{l}\text { OR } \\
\text { prioritization }\end{array}$ & & \\
\hline $\begin{array}{l}\text { Surgical } \\
\text { approaches }\end{array}$ & & $\begin{array}{l}\text { Non-operative } \\
\text { management }\end{array}$ & & & ERAS & $\begin{array}{l}\begin{array}{l}\text { Mode of } \\
\text { delivery }\end{array} \\
\end{array}$ & $\begin{array}{l}\text { endoscopic vs. } \\
\text { lap vs. open }\end{array}$ \\
\hline Infection control & $\begin{array}{l}\text { COVID-19 } \\
\text { positive } \\
\text { staff }\end{array}$ & $\begin{array}{l}\text { Aerosol generating } \\
\text { procedure } \\
\text { precautions; physical, } \\
\text { procedural, PPEs; use } \\
\text { of masks \& limits }\end{array}$ & & $\begin{array}{l}\text { decontamination; } \\
\text { team with PPE }\end{array}$ & $\begin{array}{l}\text { Preoperative } \\
\text { assessment }\end{array}$ & $\begin{array}{l}\text { Temporary } \\
\text { isolation }\end{array}$ & $\begin{array}{l}\text { RT-PCR, } \\
\text { antibody, } \\
\text { universal vs. } \\
\text { selective; } \\
\text { imaging } \\
\end{array}$ \\
\hline Diagnostics & & Digital imaging & & & & $\begin{array}{l}\text { Prenatal } \\
\text { ultrasound and } \\
\text { lung scan }\end{array}$ & \\
\hline Patient welfare & & & $\begin{array}{l}\text { Parental presence } \\
\text { for pediatric } \\
\text { patients; } \\
\text { coordinated } \\
\text { transfer, hospital } \\
\text { networks }\end{array}$ & & Palliative care & & \\
\hline \multicolumn{8}{|l|}{ Staff welfare } \\
\hline $\begin{array}{l}\text { Operations } \\
\text { protocols }\end{array}$ & $\begin{array}{l}\text { Operations } \\
\text { manual }\end{array}$ & Trauma response & & & & & \\
\hline Training & $\begin{array}{l}\text { COVID-19 } \\
\text { activities; } \\
\text { surgical } \\
\text { procedures }\end{array}$ & & & & & & \\
\hline Monitoring & $\begin{array}{l}\text { Staff health } \\
\text { and welfare }\end{array}$ & & & & & & \\
\hline Communication & & Online consultation & Parent contact & & $\begin{array}{l}\text { Online patient } \\
\text { follow-up }\end{array}$ & & \\
\hline
\end{tabular}

6. Responders should attend to trauma cases expeditiously, but also cautiously-ensuring the protection of patients, personnel, and even equipment.

7. Organizational, structural, and personal protection measures should be in place in EDs to minimize infection risks especially from aerosol-generating procedures. Emergency response protocols, modified for pandemic contingencies, should be in place, for which the staff should have had prior training and adequate practice.
8. Diagnostic imaging studies should be resorted to only if clinically warranted, with infection protection measures provided to the patient as well as others in the respective areas.

9. Non-operative management options are preferably adopted for trauma patients whenever these are appropriate.

10. Symptom monitoring, as well as contact tracing procedures, should be initiated for ED patients and their companions. 
11. Admissions criteria can be altered during pandemics to enable hospitals to conserve resources while still providing optimal care to specified patients. The criteria should be developed collectively, communicated broadly, and reassessed periodically.

12. Patients should be assessed on clinical grounds, and priority should be given to those who stand to benefit most from hospital admission, COVID-19 status notwithstanding.

13. Patients who cannot be accommodated in a facility should still receive all necessary care, including, if needed, an arranged transfer to a suitable hospital.

14. Procedural and structural measures will need to be put in place to minimize transmission risks for patients admitted to hospitals.

15. Inpatients, particularly children, are best accompanied by a family member or other designated companion unless the presence of the latter poses substantial risks for the patient or staff.

16. During crisis standards of care, $\mathrm{OR}$ access should be limited to patients in need of immediate or urgent surgical interventions.

17. A triage system, based primarily on clinical parameters, should be instituted to be able to objectively and transparently prioritize emergent surgeries. Triage officers may be designated to facilitate the implementation of the system, including communicating the allocation basis and decisions to patients and their families.

18. Patients known or suspected to have COVID-19, unless there are overriding medical contraindications or logistical constraints, should, in emergencies, still be provided the required surgical care.

19. Patients who, consequent to the application of the triage system, are not prioritized for surgery, should continue to receive supportive care as well as be given alternative options, including palliative care.

20. Structural and procedural adjustments should be adopted to ensure optimal infection control as well as rapid and adequate response in ORs, especially for emergent cases.

21. Patients whose conditions may irreversibly worsen with further delays should not be arbitrarily disqualified from receiving the needed surgical care during pandemics.

22. As patients with COVID-19 may have worse postoperative outcomes, then their respective surgical procedures should be deferred unless these are necessary.

23. If hospital capacities are still relatively limited, triage protocols should be used to objectively prioritize patients with time-critical conditions that require surgery.
24. Cancer patients for whom the required surgical interventions are still not possible should be monitored, given alternative treatments, or referred to more suitable facilities.

25. Further enrollment of cancer patients in clinical trials should be restricted during pandemics.

26. Patients whose conditions may irreversibly worsen with further delays should not be arbitrarily disqualified from receiving the needed surgical care during pandemics.

27. As patients with COVID-19 may have worse postoperative outcomes, then their respective surgical procedures should be deferred unless these are necessary.

28. If hospital capacities are still relatively limited, triage protocols should be used to objectively prioritize patients with time-critical conditions that require surgery.

29. Cancer patients for whom the required surgical interventions are still not possible should be monitored, given alternative treatments, or referred to more suitable facilities.

30. Further enrollment of cancer patients in clinical trials should be restricted during pandemics.

\section{CONCLUSION}

An action research involving a review of the literature and stakeholder engagement has provided a concise ethical and technical resource for surgical administrators, practitioners, and trainees. The work attempts to fill in many conceptual as well as practical gaps in the provision of surgical care during a pandemic and is meant to be of value both for the PGH as well as most other local institutions.

\section{Statement of Authorship}

All authors participated in the data collection and analysis and approved the final version submitted.

\section{Author Disclosure}

All authors declared no conflicts of interest.

\section{Funding Source}

This paper was funded by the Philippine General Hospital-Expanded Hospital Research Office.

\section{REFERENCES}

1. Caballes A and Lapitan M (eds). Pandemic Surgery. An Integrated Ethical and Technical Reference. [internet] Philippine General Hospital 2020. (cited 1 February 2021). Available from: https://www. nuffieldbioethics.org/assets/pdfs/PGH-Pandemic-Surgery-2020Ed-1.pdf 